DOI: $10.26418 /$ positron.v11i2.46780

\title{
Sirkulasi Laut dan Biogeokimia di Kawasan Teluk Cendrawasih
}

Aldo Darmawan ${ }^{a^{*}}$, Agus S. Atmadipoerab ${ }^{b}$ Dwiyoga Nugrohoc, M. Mukhlis Kamald, M. Ariane Koch-Larrouy

\author{
aProgram Studi Ilmu Kelautan, Sekolah Pascasarjana, IPB University, Bogor, Jawa Barat \\ bDepartemen Ilmu dan Teknologi Kelautan, FPIK, IPB University, Bogor, Jawa Barat \\ 'Badan Riset Kelautan dan Perikanan, KKP, Jakarta \\ dDepartemen Manajemen Sumberdaya Perairan, FPIK, IPB University, Bogor, Jawa Barat \\ eLEGOS, Obs. Midi-Pyrenes Toulouse France \\ *Email aldodarmawan@apps.ipb.ac.id \\ (Diterima 17 Mei 2021; Disetujui 5 Desember 2021; Dipublikasikan 29 Desember 2021)
}

\begin{abstract}
Abstrak
Teluk Cendrawasih (TC) merupakan salah satu teluk terbesar di Indonesia dan merupakan teluk semi tertutup yang memiliki biodiversitas hayati laut tinggi. Lokasi TC yang berada dekat ekuator dan berhadapan dengan Ekuator Samudera Pasifik bagian barat diduga memiliki dinamika dan variabilitas laut yang unik. Penelitian ini bertujuan untuk mengkaji pola sirkulasi laut, variabilitas arus, biogeokimia serta pengaruh fenomena El Nino Southern Oscillation (ENSO) di kawasan TC. Dataset deret-waktu yang digunakan adalah keluaran model sirkulasi laut dari Infrastructure Development of Space Oceanography (INDESO) dari tahun 2008-2015. Hasil penelitian terungkap bahwa pola sirkulasi arus permukaan di luar teluk dicirikan dengan pembalikan arah arus dua kali dalam setahun yang sejalan dengan pembalikan angin muson, sedangkan di dalam TC arus permukaan cenderung selalu mengalir keluar teluk. Sirkulasi di kedalaman 110 m dicirikan dengan dominasi Arus Pantai Papua (APP) yang bergerak secara permanen sepanjang tahun menuju barat laut dan terlihat terbentuk pusaran arus (eddy) pada musim timur. Arus muson terlihat sampai kedalaman 50 m, sedangkan APP berada pada kolom dari 50 m sampai $200 \mathrm{~m}$ (di Selat Biak) dan sampai $1000 \mathrm{~m}$ (di sisi Pasifik) dengan kecepatan maksimum 0,75 m/s. Rerata dan simpangan baku dari volume transpor APP adalah -25,25 $( \pm 11,1)$ Sv, sedangkan di Selat Biak $-0,8756( \pm 0,5)$ Sv. Variabilitas dari transpor APP didominasi periodisitas tahunan. Rerata volume transpor di pintu masuk barat TC adalah 0,03 $( \pm 0,1096) \mathrm{Sv}$ dimana variabilitasnya pada periode intra musiman. Variabilitas beberapa parameter biogeokimia di TC dan Pasifik didominasi periodisitas antar tahunan, tahunan dan intra musiman. Variasi antar tahunan dari parameter tersebut berkoherensi kuat dengan suhu permukaan laut di kawasan ekuator Pasifik, sebagai wilayah ENSO.
\end{abstract}

Kata kunci: Arus Pantai Papua, ENSO, INDESO, Teluk Cendrawasih, variabilitas

\section{Latar Belakang}

Teluk Cendrawasih (TC) adalah teluk terbesar yang ada di Indonesia dan tergolong perairan semi tertutup karena keberadaan Pulau Yapen dan Biak. Sebagai bagian wilayah coral triangle, TC memiliki biodiversitas hayati laut yang tinggi terutama spesies ikan karang dan terumbu karang terkaya di dunia, sehingga dianggap sebagai pusat keanekaragaman hayati laut global di perairan dangkal kawasan tropis [1,2].

Dinamika dan variabilitas perairan TC lebih banyak dipengaruhi oleh keberadaan Samudera Pasifik bagian barat, yang letaknya berada di dekat Ekuator. Pengaruh variasi musiman angin muson terlihat jelas menimbulkan variabilitas arus akibat pembalikan arah angin di permukaan laut Utara Papua [3]. Selain itu, angin pasat mempengaruhi wilayah kajian yang dominan bergerak ke arah barat sepanjang tahun [4] dan menjadikan perairan utara Papua dikenal sebagai kolam air hangat Samudera Pasifik Barat yang memiliki rata-rata suhu permukaan laut $>28^{\circ} \mathrm{C}$ [5].

Fenomena El Nino Southern Oscillation (ENSO) ikut serta dalam mempengaruhi variabilitas parameter fisik di wilayah Papua seperti arus zonal, volume transpor, suhu dan salinitas [6,7]. Peristiwa El Nino (fase hangat) ditandai dengan peningkatan suhu permukaan laut di Samudera Pasifik bagian tengah dan timur, serta terjadi penurunan hujan di wilayah benua maritim Indonesia, sedangkan peristiwa La Nina (fase dingin) memiliki kondisi yang berkebalikan.

Perairan Utara Papua juga dilewati oleh sistem arus yang termasuk dalam Low-Latitude Western Boundary Currents (LLBWCs) di Samudera Pasifik bagian barat. Arus ini dikenal sebagai Arus Pantai Papua yang mengalir di dekat permukaan laut (New Guinea Coastal Current - NGCC) dan yang mengalir di lapisan termoklin ke bawah (New Guinea Coastal 
Undercurrent - NGCUC) $[6,8,9]$. Kedua arus tersebut membawa massa air, suhu dan salinitas dari wilayah Utara Papua $[3,10]$. Selain itu kedua arus ini membawa massa air South Pasific Tropical Water (SPTW) yang kaya akan nutrien (nitrat, fosfat dan silikat) dan unsur besi $(\mathrm{Fe})[11,12]$.

Berbagai penelitian mengenai arus NGCC/NGCUC serta pengaruh fenomena ENSO terhadap parameter fisik telah banyak dilakukan di wilayah Pantai Utara Papua, namun kajian khusus di kawasan TC masih jarang. Oleh karena itu, penelitian ini bertujuan untuk mengkaji pola sirkulasi, variabilitas arus NGCC/NGCUC, biogeokimia dan korelasinya dengan variasi iklim antar tahunan ENSO di kawasan TC.

\section{Metodologi}

\section{A. Waktu dan lokasi Penelitian}

Penelitian ini dilaksanakan pada bulan Januari-Maret 2021 di Laboratorium Oseanografi Fisika Departemen Ilmu dan Teknologi Kelautan, FPIK IPB Bogor. Wilayah kajian di kawasan TC dengan koordinat $131,5-141^{\circ} \mathrm{E}$ dan $3,5^{\circ} \mathrm{S}-3^{\circ} \mathrm{N}$ (Gambar 1). Wilayah studi meliputi dua sampling box (kotak merah) dan dua transek yaitu transek AB $\left(135^{\circ} \mathrm{E} ; 3,5^{\circ} \mathrm{S}-3^{\circ} \mathrm{N}\right)$ dan C-D $\left(134,15-135,42^{\circ} \mathrm{E}\right.$; $\left.1,8^{\circ} \mathrm{S}\right)$.

\section{B. Data Model}

Dataset untuk penelitian ini diperoleh dari program Infrastructure Development of Space
Oceanography (INDESO), yaitu berupa keluaran hasil simulasi model sirkulasi umum laut NEMO yang dilakukan oleh CLS France \& BPOL Bali. Rentang waktu dataset dari 1 Januari 2008 hingga 31 Desember 2015. INDESO merupakan program kerjasama ilmiah di Kementerian Kelautan dan Perikanan dengan konsorsium bersama European Marine Research Institute (MERCATOR - Ocean and Collecte Localization Satelittes - CLS) Prancis. Resolusi spasial dari model INDESO adalah $1 / 12^{\circ}$ $(9,25 \mathrm{~km})$ dan 50 lapisan vertikal. Konfigurasi dan forcing dari model INDESO telah dijelaskan oleh Tranchant et al [13]. Parameter yang digunakan dari model ini adalah rerata harian dari parameter fisika (seperti arus, suhu, salinitas, dan tinggi muka laut) dan parameter biogeokimia (nutrien, plankton, dan produktivitas primer). Parameter biogeokimia merupakan hasil couple antara model INDESO dengan model Pelagic Interactions Scheme for Carbon and Ecosystem Studies (PISCES).

\section{C. Validasi Data}

Data hasil model INDESO terlebih dahulu dilakukan validasi untuk melihat kinerja dan akurasinya. Parameter suhu permukaan laut (sea surface temperature/SST) dan tinggi muka air laut (sea surface height/SSH) dari model INDESO divalidasi dengan satelit MetOp AVHRR dan satelit altimetri Duacs. Validasi model INDESO menggunakan diagram Taylor [14]. Diagram Taylor memberikan gambaran tentang seberapa dekat

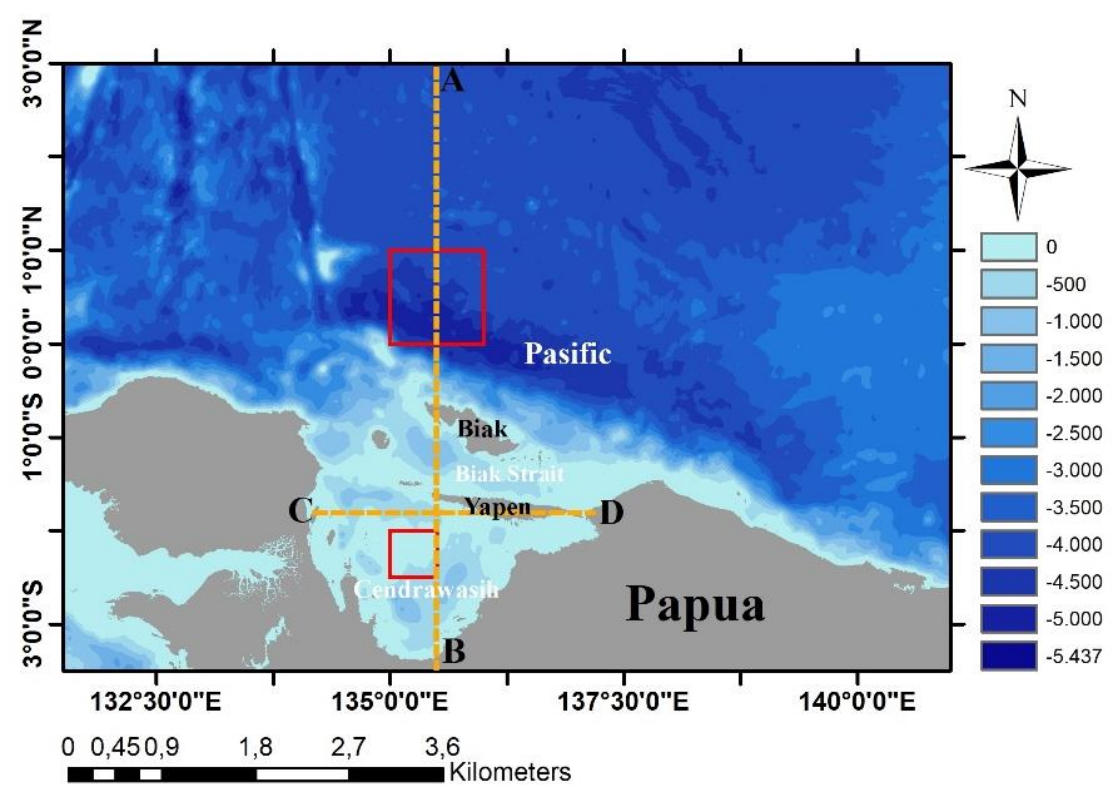

Gambar 1. Lokasi penelitian di wilayah Teluk Cendrawasih (TC). Transek A-B dan C-D untuk perhitungan volume transpor arus NGCC/NGCUC dan arus keluar-masuk TC. Dua sampling box merah adalah kotak pengambilan sampel untuk validasi antara model dengan satelit. 
model dengan observasi. Koefisien korelasi, standar deviasi, dan root mean square deviation (RMSD) adalah tiga parameter statistik yang ditampilkan pada diagram.

\section{D. Analisis Data}

Karakteristik sirkulasi dan variabilitas arus di wilayah studi dilihat dengan menggunakan analisis data deret waktu, seperti siklus tahunan dari spasial arus, arus musiman komponen zonal (transek A-B) dan meridional (transek C-D); analisis cross- Power Spectrum Density (cross- PSD); dan analisis Empirical Orthogonal Function (EOF), menurut Emery \& Thomson [15]. Metode klimatologi digunakan untuk menganalisis siklus tahunan variabel arus dan suhu. Metode EOF digunakan untuk menganalisis variabilitas spasial dan temporal arus NGCC/NGCUC dan arus di pintu TC bagian barat. Pengolahan dan penampilan data dilakukan dengan menggunakan perangkat lunak Pyferret.

Metode analisis cross-PSD (cross-Power Spectral Density) digunakan untuk mengetahui periodisitas bersama dari kedua data deret waktu. Derajat korelasinya ditunjukkan oleh nilai koherensi yang dinormalisasi, yang bervariasi dari minimum (0) hingga maksimum (1). Dalam penelitian ini, analisis cross-PSD digunakan untuk mengetahui korelasi antara data deret waktu dari suhu di utara TC dengan SST Indo-Pasifik, arus zonal di utara TC dengan angin zonal Indo-Pasifik.

Hasil analisis cross-PSD adalah ko-spektrum energi yang menunjukkan besarnya fluktuasi energi pada frekuensi yang sama antara dua data, koherensi dan fase menunjukkan korelasi dan perbedaan fase (tertinggal atau mendahului) pada frekuensi tertentu dalam kedua deret waktu.
Menurut Bendat \& Piersol [16], cross-PSD dihitung dengan menggunakan persamaan:

$$
\mathrm{G}_{x y}\left(f_{k}\right)=\frac{2}{N \Delta t}\left[X\left(f_{k}\right) Y\left(f_{k}\right)\right]
$$

dimana $G_{x y}$ adalah spektrum densitas energi silang pada frekuensi ke-k $\left(f_{k}\right) ; f_{k}=k / T ; k=0,1, \ldots, N /$ 2; $X\left(f_{k}\right)$ adalah komponen Fourier dari (xt); $Y\left(f_{k}\right)$ adalah komponen Fourier dari (yt); $\Delta t$ adalah selang waktu data (1 hari).

Nilai koherensi dihitung dengan menggunakan persamaan [16]:

$$
\gamma_{x y}^{2}\left(f_{k}\right)=\frac{\left|G_{x y}\left(f_{k}\right)\right|^{2}}{G_{x x}\left(f_{k}\right) G_{y y}\left(f_{k}\right)}
$$

dimana $\gamma_{x y}^{2}\left(f_{k}\right)$ adalah nilai koherensi pada frekuensi ke-k $\left(f_{k}\right) ; G_{x x}\left(f_{k}\right)$ dan $G_{y y}\left(f_{k}\right)$ adalah estimasi spektrum yang dihitung dari $x_{n}$ dan $y_{n}, n=$ $0,1, \ldots, N-1$.

Nilai beda fase dihitung dengan menggunakan persamaan [16]:

$$
\phi\left(f_{k}\right)=\tan ^{-1}\left[Q_{X Y}\left(f_{k}\right) / C_{x y}\left(f_{k}\right)\right.
$$

dimana $C_{x y}\left(f_{k}\right)$ dan $Q_{X Y}\left(f_{k}\right)$ adalah nilai nyata dan imajiner, dari $\mathrm{G}_{x y}\left(f_{k}\right)$.

Estimasi volume transpor massa air NGCC/NGCUC $(Q u)$ yang mengalir di Utara Papua dan Selat Biak pada transek AB dan massa air yang melewati pintu TC $(Q v)$ pada transek BC dapat dihitung dengan mengintegralkan kecepatan arus komponen zonal $(u)$ serta arus komponen meridional $(v)$ terhadap panjang transek dan kedalaman, yang dapat ditulis sebagai berikut [15]:

$$
Q_{u} \equiv \int_{A}^{B} \int_{z}^{0} u d y d z
$$
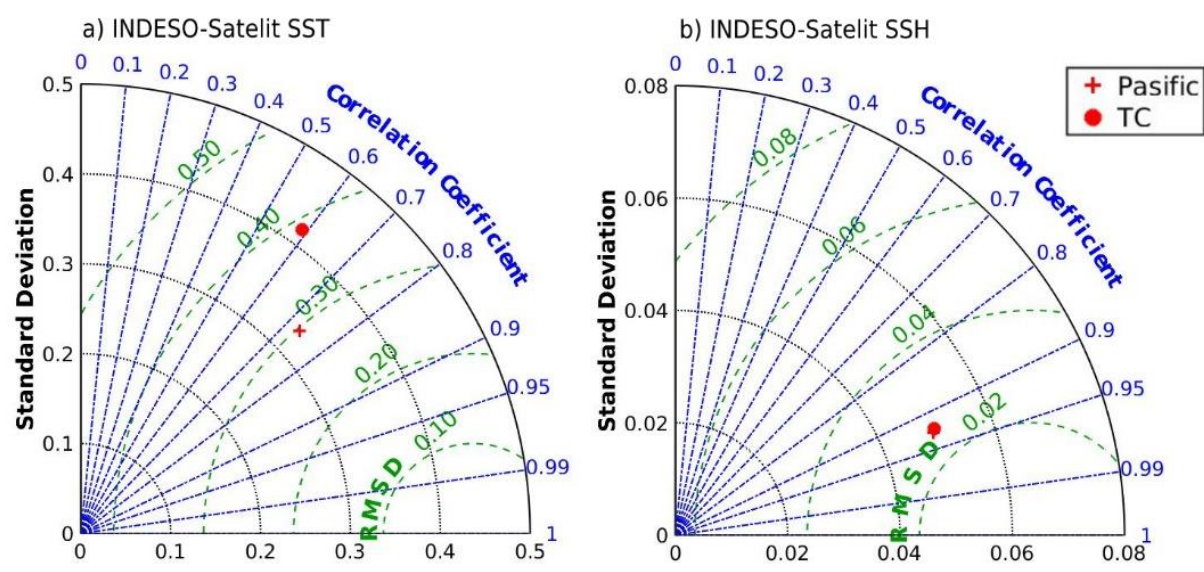

Gambar 2. Diagram Taylor dari (a) INDESO-Satelit SST dan (b) INDESO-Satelit SSH dari tahun 2008-2015 yang diambil pada sampling box TC dan Pasifik. 


$$
Q_{v} \equiv \int_{C}^{D} \int_{z}^{0} v d x d z
$$

dimana $Q_{u}$ dan $Q_{v}$ adalah total volume transpor dari arus NGCC\&NGCUC dan arus yang melewati pintu TC $\left(1 \mathrm{~Sv}=10^{6} \mathrm{~m}^{3} \mathrm{~s}^{-1}\right) ; z$ adalah batas bawah perhitungan sebesar $832 \mathrm{~m}$ untuk NGCC/NGCUC di Utara Papua, $250 \mathrm{~m}$ untuk Selat Biak dan $350 \mathrm{~m}$ untuk pintu TC, secara vertikal hingga permukaan $(0 \mathrm{~m})$; AB adalah transek pada $135,5^{\circ} \mathrm{E}\left(0,7^{\circ} \mathrm{S}-1^{\circ} \mathrm{N}\right.$ untuk Utara Papua dan $1,6^{\circ} \mathrm{S}-0,7^{\circ} \mathrm{S}$ untuk Selat Biak) dan CD adalah transek pada $1,8^{\circ} \mathrm{S}\left(134,1^{\circ} \mathrm{E}-\right.$ $\left.137,1^{\circ} \mathrm{E}\right) ; \quad u$ adalah komponen arus zonal dan $v$ komponen arus meridional $(\mathrm{m} / \mathrm{s})$.

\section{Hasil dan Pembahasan}

\section{A. Validasi Model}

Hasil validasi model INDESO dengan satelit di dua lokasi sampling box (TC dan Pasifik) ditunjukkan pada diagram Taylor (Gambar 2). Korelasi model INDESO untuk parameter SST di TC dan Pasifik bernilai 0,59 dan 0,73 dengan RMSD sebesar $0,3495{ }^{\circ} \mathrm{C}$ dan $0,2969{ }^{\circ} \mathrm{C}$; dan standar deviasi sebesar 0,4178 dan 0,3313. Parameter SSH menujukan korelasi yang tinggi di TC dan Pasifik dengan nilai sebesar 0,92 dan 0,93 dengan RMSD sebesar $0,0251 \mathrm{~m}$ dan $0,0253 \mathrm{~m}$; dan standar deviasi sebesar 0,0498 dan 0,0494. Hasil uji korelasi yang tinggi pada parameter SSH dan SST memperlihatkan bahwa model INDESO dapat merepresentasikan kondisi yang mendekati sebenarnya, sehingga dapat dianalisis lebih lanjut untuk keperluan studi ini.

\section{B. Siklus Tahunan Arus Permukaan}

Siklus tahunan arus permukaan di kedalaman $5 \mathrm{~m}$ (Gambar 3) menunjukkan bahwa arus permukaan di Pasifik dan Selat Biak bergerak menuju arah timur pada bulan Januari (musim barat) dan menuju arah barat laut pada bulan Juli (musim timur). Pergerakan arus ini dikenal dengan arus NGCC, dimana pergerakannya mengikuti dari pola angin muson. Di dalam TC, terbentuknya pusaran arus searah jarum jam/siklonik pada bulan
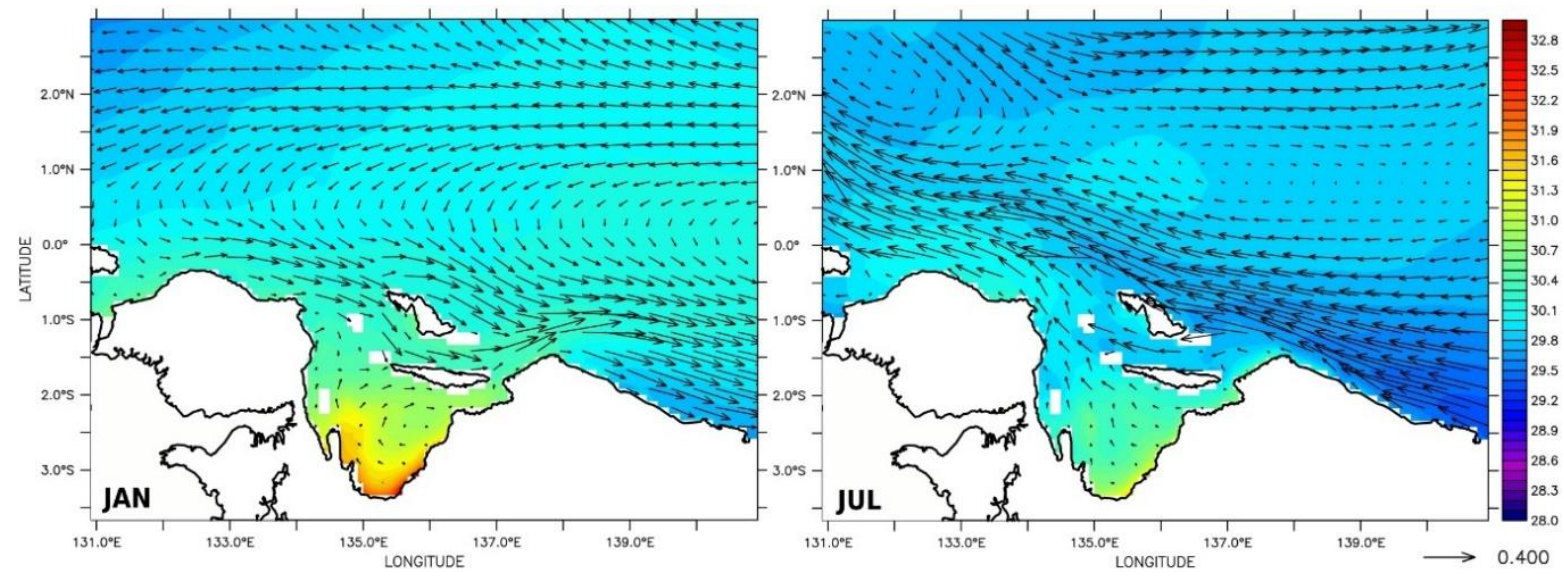

Gambar 3. Pola Sirkulasi pada kedalaman permukaan (5 m) yang di ditumpang-susun dengan suhu pada bulan Januari dan Juli.

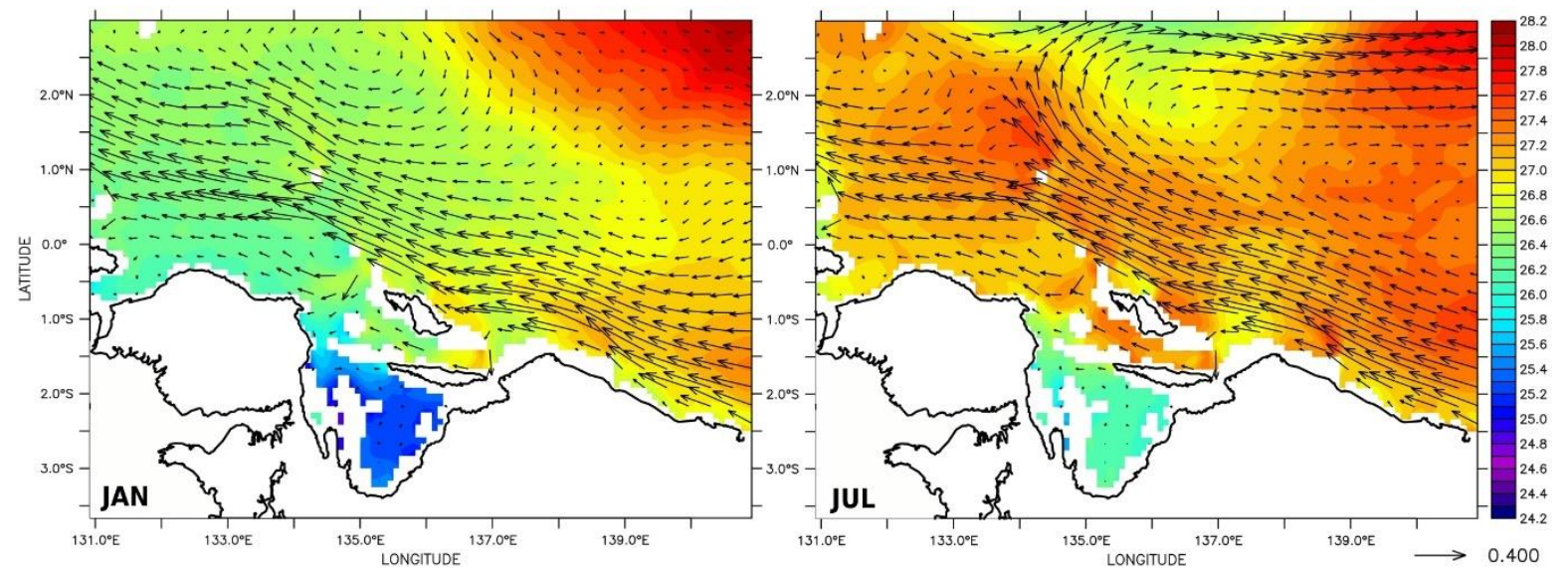

Gambar 4. Seperti pada Gambar 3, tetapi untuk kedalaman termoklin (110 m). 

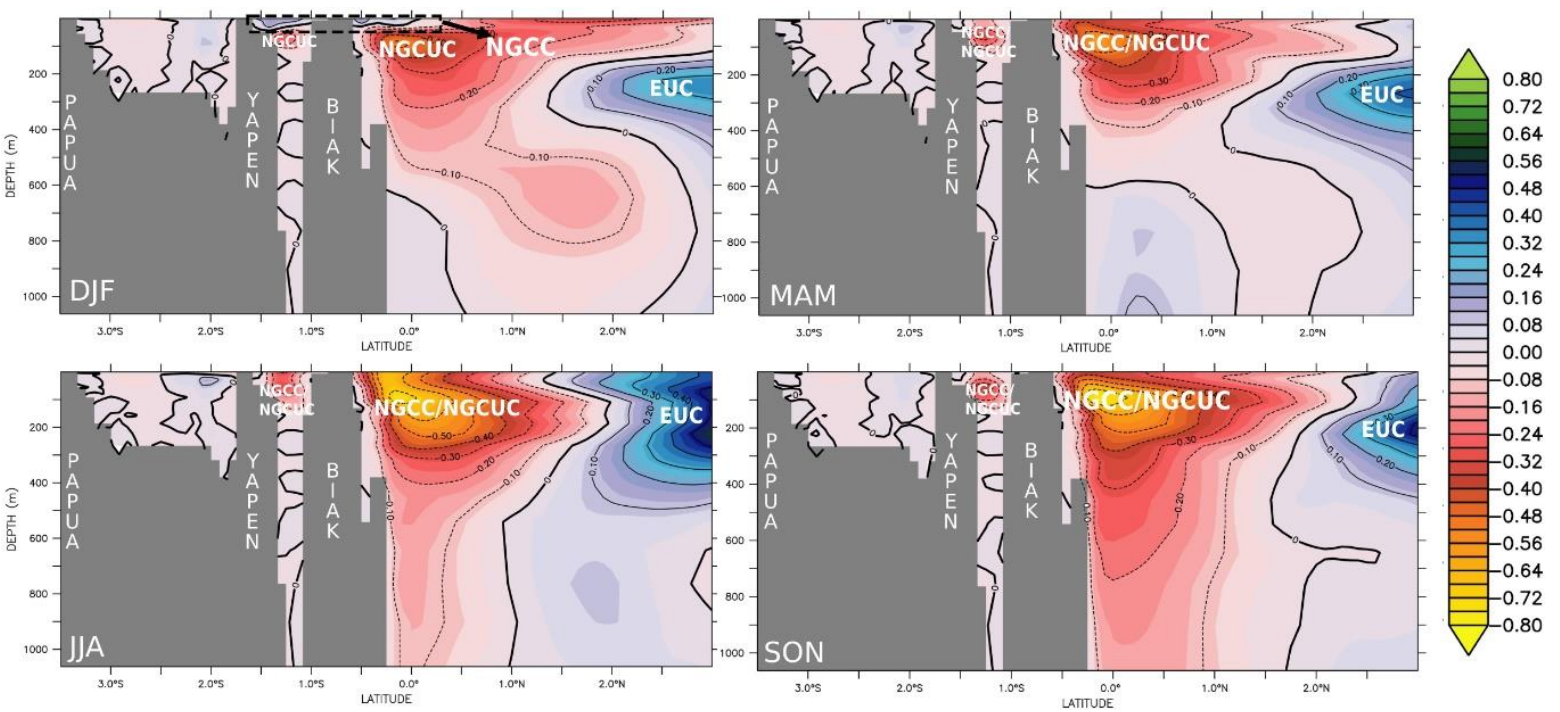

Gambar 5. Variasi musiman dari struktur menegak dari arus zonal (u) di transek A-B (lihat Gb. 1). Warna menujukan amplitude kecepatan (m/s).

Januari yang mengindikasikan terjadinya upwelling . Sedangkan pada bulan Juli, arus di TC bergerak keluar dari teluk melewati pintu barat teluk.

Arus pada kedalaman termoklin yaitu $110 \mathrm{~m}$ (Gambar 4) secara umum memperlihatkan dominasi arus NGCUC yang berada di Pasifik dan Selat Biak bergerak secara permanen menuju arah barat laut di sepanjang tahun. Arus NGCUC terlihat memiliki intensitas terkuat pada musim timur (Juli) dibandingkan dengan musim barat (Januari). Hal ini sesuai dengan penelitian yang telah dilakukan oleh Kuroda [17], bahwa NGCUC yang berada di kedalaman termoklin selalu bergerak menuju arah barat laut di setiap musim. Pada musim timur (Juli) terlihat muncul nya pusaran arus/eddy antisiklonik yang dinamakan New Guinea Eddy (NGE) [8] di sekitar $2^{\circ} \mathrm{N}$ dan $136^{\circ} \mathrm{E}$ dengan diameter mencapai $300 \mathrm{~km}$. Terbentuknya NGE menimbulkan arus NGCUC pada musim timur dan peralihan dua bergerak berbalik arah menuju timur. Pembalikan arah arus ini merupakan bagian dari arus Equatorial Undercurrent (EUC) yang massa air utamanya berasal dari arus NGCUC [9] dan disebabkan oleh adanya NGE [18].

\section{C. Variasi Musiman Struktur Menegak Arus}

Berdasarkan struktur menegak arus zonal transek A-B (Gambar 5), arus di dalam TC terlihat bergerak menuju timur di bagian barat Pulau Yapen dan bergerak menuju barat di dekat daratan Papua. Pergerakan arus ini terlihat menunjukan adanya pusaran arus siklonik. Pergerakan arus di dalam teluk ini terlihat lemah dari permukaan hingga dasar teluk dengan kecepatan berkisar -0,08 hingga $0,1 \mathrm{~m} / \mathrm{s}$.

Arus NGCC/NGCUC terlihat dari struktur menegak di Pasifik $\left(0,5^{\circ} \mathrm{S}-2^{\circ} \mathrm{N}\right)$ dan Selat Biak. Arus NGCC/NGCUC di Pasifik terlihat berada dari Pantai Pulau Biak sampai $2^{\circ} \mathrm{N}$, dengan pusat berada dari $0,5^{\circ} \mathrm{S}-0,5^{\circ} \mathrm{N}$. Arus zonal musim barat (Januari) memperlihatkan adanya arus NGCC yang bergerak menuju arah timur (positif/warna biru) dan arus NGCUC yang bergerak menuju arah barat (negatif/warna merah).

Arus NGCC yang bergerak menuju timur pada musim ini mencapai kedalaman kurang dari $50 \mathrm{~m}$ di wilayah Selat Biak dan Pasifik. Hal ini mengkonfirmasi Kashino et al [8] bahwa NGCC merupakan arus permukaan $(<100 \mathrm{~m})$ yang dipengaruhi oleh musim, bergerak menuju barat laut saat musim barat dan berbalik arah pada musim timur. Memasuki musim peralihan satu (MAM), arus NGCC berbalik arah menuju barat dan arus NGCUC terlihat menjadi lebih kuat dari musim barat. Arus NGCC/NGCUC musim timur (JJA) memiliki kecepatan tertinggi dari semua musim di Pasifik dan Selat Biak, dimana kecepatan mencapai $0,75 \mathrm{~m} / \mathrm{s}(100 \mathrm{~m})$ dan $0,65 \mathrm{~m} / \mathrm{s}$ (permukaan) di Pasifik, sedangkan di Selat Biak mencapai $0,25 \mathrm{~m} / \mathrm{s}$ baik di permukaan dan kedalaman $100 \mathrm{~m}$. Musim peralihan dua memiliki kecepatan arus NGCUC yang hampir sama dengan musim timur, sedangkan arus NGCC di permukaan mengalami pelemahan.

Arus NGCUC (Gambar 5) di Pasifik terlihat memiliki kedalaman yang berbeda-beda. Kedalaman arus NGCUC pada musim peralihan satu 

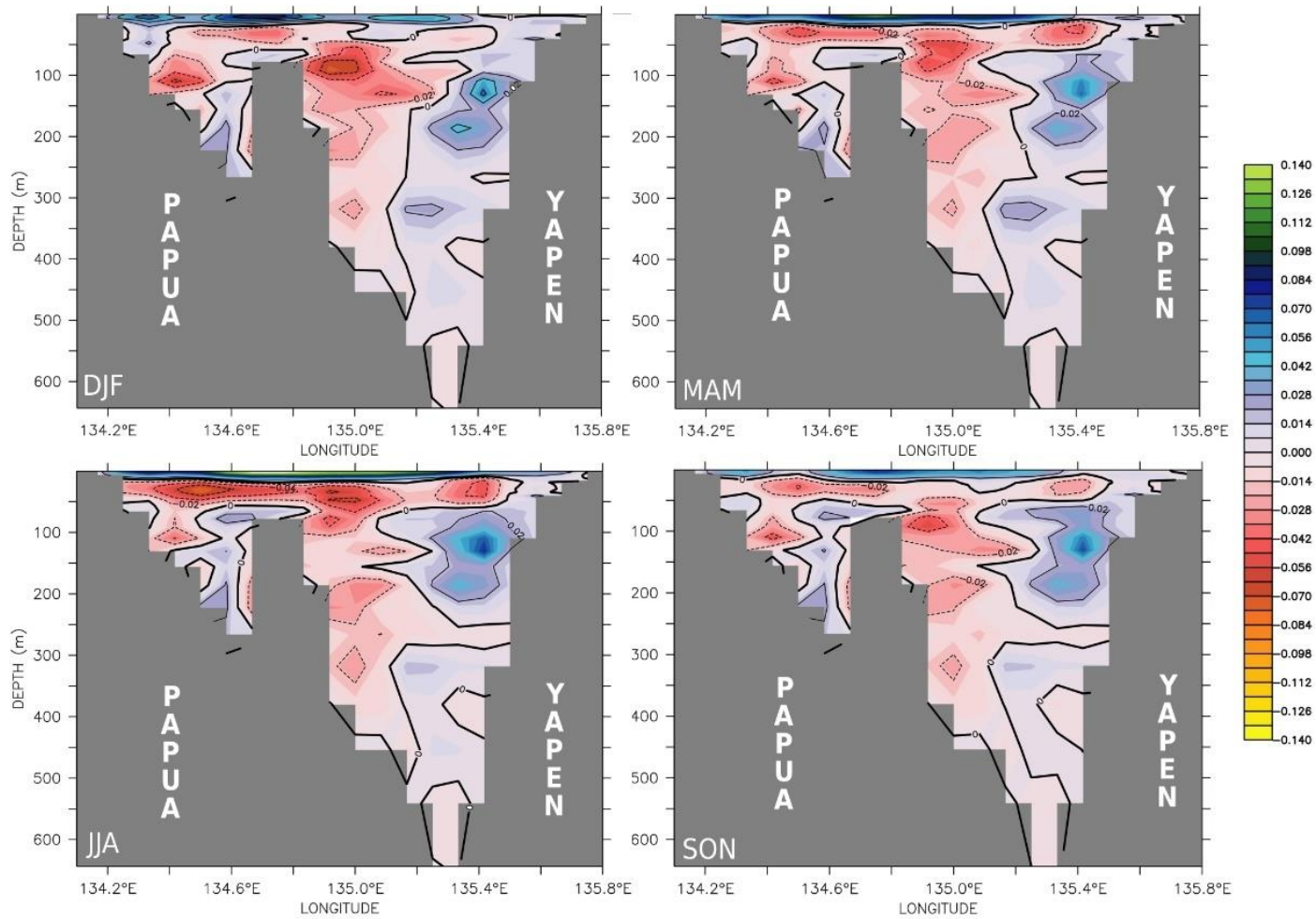

Gambar 6. Variasi musiman dari Struktur menegak arus meridional (v) dari pintu barat TC pada transek C-D (lihat Gb. 1). Warna menujukan amplitude kecepatan (m/s).

hanya mencapai $400 \mathrm{~m}$, sedangkan musim lain memiliki kedalaman mencapai 1000 m. Kecepatan maksimum arus NGCUC terlihat berada pada kedalaman $100 \mathrm{~m}$ di semua musim. Kecepatan maksimum arus NGCUC di Pasifik ini terlihat lebih dangkal dibandingkan penelitian yang dilakukan oleh Zhang et al [7] dan Ueki et al [6], dengan mengukur menggunakan ADCP di punggung Pantai Papua. Pengukuran ADCP oleh Ueki et al [6] berada di $142^{\circ} \mathrm{E}, 2,5^{\circ} \mathrm{S}$ dan $142^{\circ} \mathrm{E}, 2^{\circ} \mathrm{S}$ di atas kedalaman $250 \mathrm{~m}$, menemukan arus NGCUC di kedalaman 150$250 \mathrm{~m}$ dengan kecepatan maksimum lebih dari -50 $\mathrm{cm} / \mathrm{s}$ di sekitar kedalaman $200 \mathrm{~m}$. Mooring ADCP oleh Zhang et al [7] berada di $141,4^{\circ} \mathrm{E}, 1,7^{\circ} \mathrm{S}$ dan $142^{\circ} \mathrm{E}, 1^{\circ} \mathrm{S}$ di atas $800 \mathrm{~m}$, menemukan arus NGCUC di kedalaman 100-400 m dengan kecepatan maksimum sekitar $-40( \pm 10) \mathrm{cm} / \mathrm{s}$ di kedalaman $200 \mathrm{~m}$.

Arus wilayah Samudera Pasifik $\left(2^{\circ} \mathrm{N}\right)$, ditemukan adanya cabang arus Equatorial Undercurrent (EUC) yang merupakan arus subsurface dan bergerak menuju timur di termoklin Ekuator Samudera Pasifik. Gambar 5 menunjukkan secara konsisten arus EUC bergerak menuju timur pada kedalaman 200-300 m, kecuali pada musim timur yang mencapai kedalaman permukaan. Hal ini sesuai dengan penelitian Ueki et al [6], inti dari arus EUC berada pada kedalaman 220 m. Cabang arus EUC terlihat memiliki kecepatan maksimum sebesar $0,5 \mathrm{~m} / \mathrm{s}$ di musim timur dan peralihan dua, dimana arus EUC menguat pada musim timur dan melemah pada musim barat [6].

Struktur menegak arus meridional transek CD di pintu barat TC (Gambar 6) menunjukan adanya arus yang masuk ke TC (merah/negatif) dan keluar TC (biru/positif). Arus yang masuk ke dalam teluk secara umum berada di kedalaman sekitar $20 \mathrm{~m}$ sampai $500 \mathrm{~m}$, serta menujukan kecepatan yang hampir sama di musim barat sampai musim timur dan lemah di musim peralihan dua. Arus yang keluar dari TC berada di permukaan dan dekat dengan Pulau Yapen, dimana kecepatan tertinggi arus yang keluar berada pada musim timur. Arus yang keluar dan masuk ke dalam TC memiliki kecepatan yang rendah antara $0 \mathrm{~m} / \mathrm{s}$ dan $0,14 \mathrm{~m} / \mathrm{s}$.

\section{D. Variabilitas Volume Transpor}

Data deret waktu volume transpor NGCC/NGCUC Pasifik dari Januari 2008 sampai Desember 2015 menunjukkan kisaran fluktuasi antara $-51,13 \mathrm{~Sv}$ dan $-1,49 \mathrm{~Sv}$ (ke arah barat), dengan rata-rata sebesar $-25,25 \quad( \pm 11,1) \quad \mathrm{Sv}$ (Gambar 7a). Siklus tahunan dari volume transpor NGCC/NGCUC (Gambar 7b) memperlihatkan nilai volume transpor yang kuat selama musim peralihan dua, yang mencapai puncak pada bulan 
Oktober (-39 Sv) dan melemah memasuki musim barat sampai dengan bulan April (-13 Sv). Nilai volume transpor NGCC/NGCUC telah dihitung atau diestimasi di punggung Pantai Papua dan kepala burung Papua oleh beberapa peneliti. Ueki et al [6] memperkirakan nilai volume transpor $\mathrm{di}$ kedalaman 40-500 $\mathrm{m}$ dari SADCP pada punggung Pantai Papua $\left(142^{\circ} \mathrm{E}, 1^{\circ} \mathrm{S}\right)$ sebesar $-26,9 \mathrm{~Sv}$. Zhang et al [7] mendapatkan nilai volume transpor tahun $1980-2018$ di punggung Pantai Papua $\left(142^{\circ} \mathrm{E}, 1^{\circ} \mathrm{S}\right)$ pada kedalaman $0-400 \mathrm{~m}$ sebesar $-14,2 \mathrm{~Sv}$ menggunakan model OFES. Wattimena et al [19] mendapatkan nilai volume transpor di kepala burung Papua $\left(133^{\circ} \mathrm{E}, 0,5^{\circ} \mathrm{S}-2^{\circ} \mathrm{N}\right)$ pada kedalaman 0-800 m sebesar $-18.3( \pm 8,3) \mathrm{Sv}$ dari hasil model INDESO.
Berdasarkan hasil analisis PSD dari komponen arus zonal di Pasifik (Gambar 7c), data deret-waktu volume transpor arus NGCC/NGCUC di Pasifik memiliki periodisitas energi signifikan yang terjadi pada skala-waktu dominan tahunan (341 hari) dan terlihat adanya skala-waktu antar tahunan $(2,8$ tahun) dan intra musiman (64 hari). Pengaruh skala-waktu antar tahunan (ENSO) terhadap volume transpor NGCC/NGCUC terlihat dalam tahun La Nina (2008-2009; 2011-2012), volume transpor NGCC/NGCUC menjadi lebih kuat seperti pada musim peralihan dua pada tahun 2008 dan 2011. Sebaliknya, dalam tahun El Nino (2009-2010; 2015-2016), arus NGCC/NGCUC menjadi lebih lemah seperti di tahun 2009.

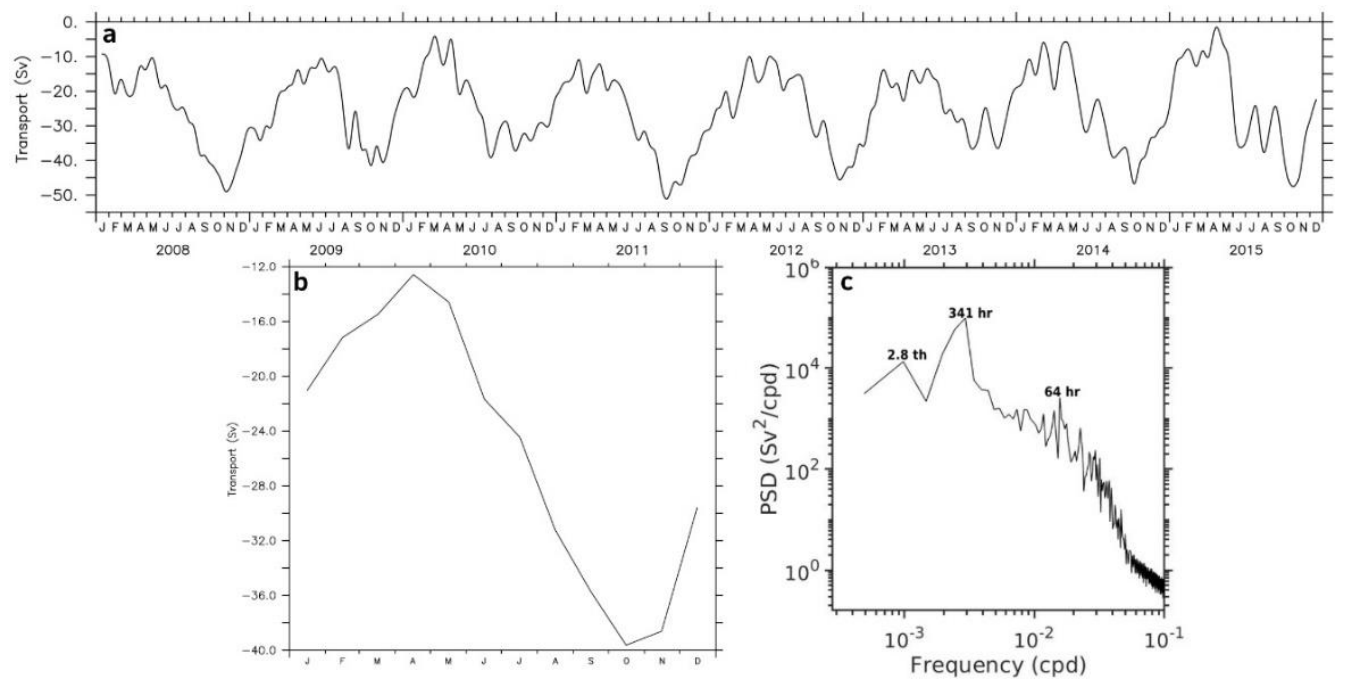

Gambar 7. (a) Deret waktu dari volume transpor (0-832 m), (b) siklus tahunannya dan (c) analisis PSD di wilayah NGCC/NGCUC Pasifik.

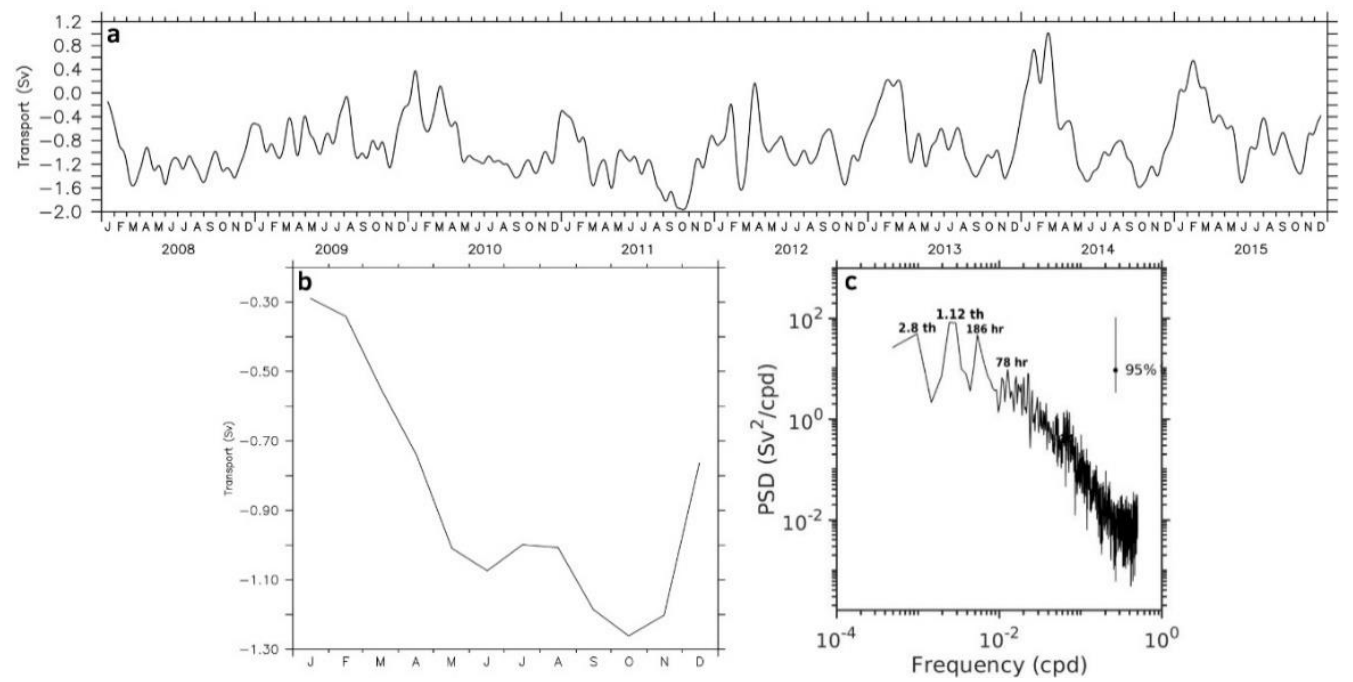

Gambar 8. (a) Deret waktu dari volume transpor (0-250 m), (b) siklus tahunannya dan (c) analisis PSD di wilayah NGCC/NGCUC Selat Biak. 


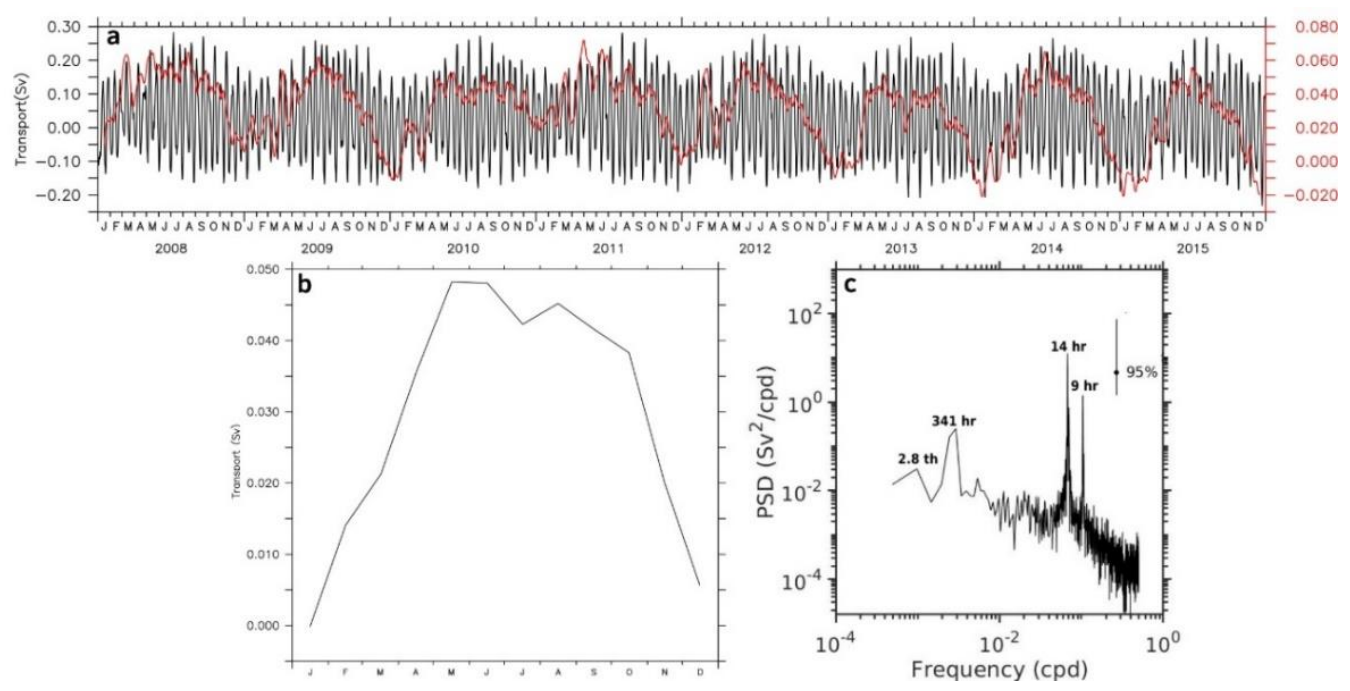

Gambar 9. (a)Deret waktu dari volume transpor (0-350 m), (b)Siklus tahunannya dan (c) analisis PSD di wilayah pintu barat TC.

Volume transpor NGCC/NGCUC di Selat Biak menujukkan fluktuasi antara $-1,965 \mathrm{~Sv}$ dan 1,012 $\mathrm{Sv}$, dengan rata-rata sebesar $-0,8756( \pm 0,5) \mathrm{Sv}$ (Gambar 8a). Siklus tahunan dari volume transpor NGCC/NGCUC di Selat Biak (Gambar 8b) memperlihatkan volume transpor menguat di musim peralihan dua dan mencapai puncaknya di bulan Oktober $(1,25 \mathrm{~Sv})$. Volume transpor mengalami pelemahan sampai $0,3 \mathrm{~Sv}$ di bulan Januari, musim barat. Berdasarkan hasil analisis PSD dari komponen zonal di Selat Biak (Gambar 8c), data deret waktu volume transpor memiliki periodisitas energi signifikan pada skala-waktu tahunan (409 hari), antar tahunan (2,8 tahun), semi-tahunan (186 hari) yang terlihat dominan dan juga terdapat skala-waktu intra musiman (78 dan 43 hari).

Data deret waktu volume transpor arus di pintu barat TC (Gambar 9a) menunjukkan adanya fluktuasi pasang surut yang kuat (garis hitam) serta dari hasil panapisan 30 hari (garis merah) menunjukkan adanya skala tahunan. Kisaran fluktuasi dari transpor pintu TC antara $-0,2321 \mathrm{~Sv}$ (masuk teluk) dan 0,2838 Sv (keluar teluk), dengan rata-rata sebesar 0,03 $( \pm 0,1096) \mathrm{Sv}$. Siklus tahunan dari volume transpor arus ini (Gambar 9b) memperlihatkan nilai volume transpor yang kuat berada di bulan Maret dan Juli, serta rendah pada musim barat (DJF). Berdasarkan hasil analisis PSD (Gambar 9c) dari komponen meridional, diperoleh periodisitas energi signifikan dominan pada skalawaktu intra musiman (14 dan 9 hari), serta terdapat skala waktu tahunan (341 hari) dan antar tahunan (2,8 tahun).

\section{E. Pola Spasial dan Variasi Temporal Arus NGCC/NGCUC}

Struktur spasial dari arus NGCC/NGCUC dapat dilihat dari hasil analisis EOF untuk arus zonal (Gambar 10), dengan empat mode utama dari presentasi varians terbesar (EOF mode 1 - mode 4) mencapai $84,88 \%$. EOF mode 1 dengan varians $50,22 \%$, memiliki sinyal amplitudo terkuat yang ditemukan di Pasifik dengan nilai 0,65. Pola pada EOF mode 1 ditemukan aliran NGCC/NGCUC yang bergerak ke arah barat di Pasifik maupun di Selat Biak yang ditunjukkan dengan nilai negatif, sedangkan nilai positif menunjukkan resirkulasi arus menuju timur yang merupakan arus EUC. EOF mode 2 dengan varians 15,81\% memiliki nilai positif di kedalaman lebih dari $100 \mathrm{~m}$. EOF mode 3 dengan varians 9,6\% memperlihatkan nlai negatif di permukaan Pasifik dan Selat Biak yang diduga arus NGCC yang bergerak ke arah timur. EOF mode 4 dengan varians $3,71 \%$ memiliki nilai positif di permukaan sampai kedalaman $250 \mathrm{~m}$.

Variasi temporal dari data deret waktu yang bersesuaian dengan EOF mode 1 - mode 4 serta hasil analisis power spectral density (PSD) disajikan pada Gambar 11. Berdasarkan hasil analisis energi densitas EOF mode 1 sampai mode 4, fluktuasi arus zonal memiliki dominan siklus tahunan yaitu 341 hari. Variabilitas semi-tahunan ditemukan pada EOF mode 2 (183 hari) dan 4 (178 hari), serta variabilitas intra musiman di EOF mode 2 (43 hari) dan mode 3 (78 hari). Hal ini sesuai dengan 


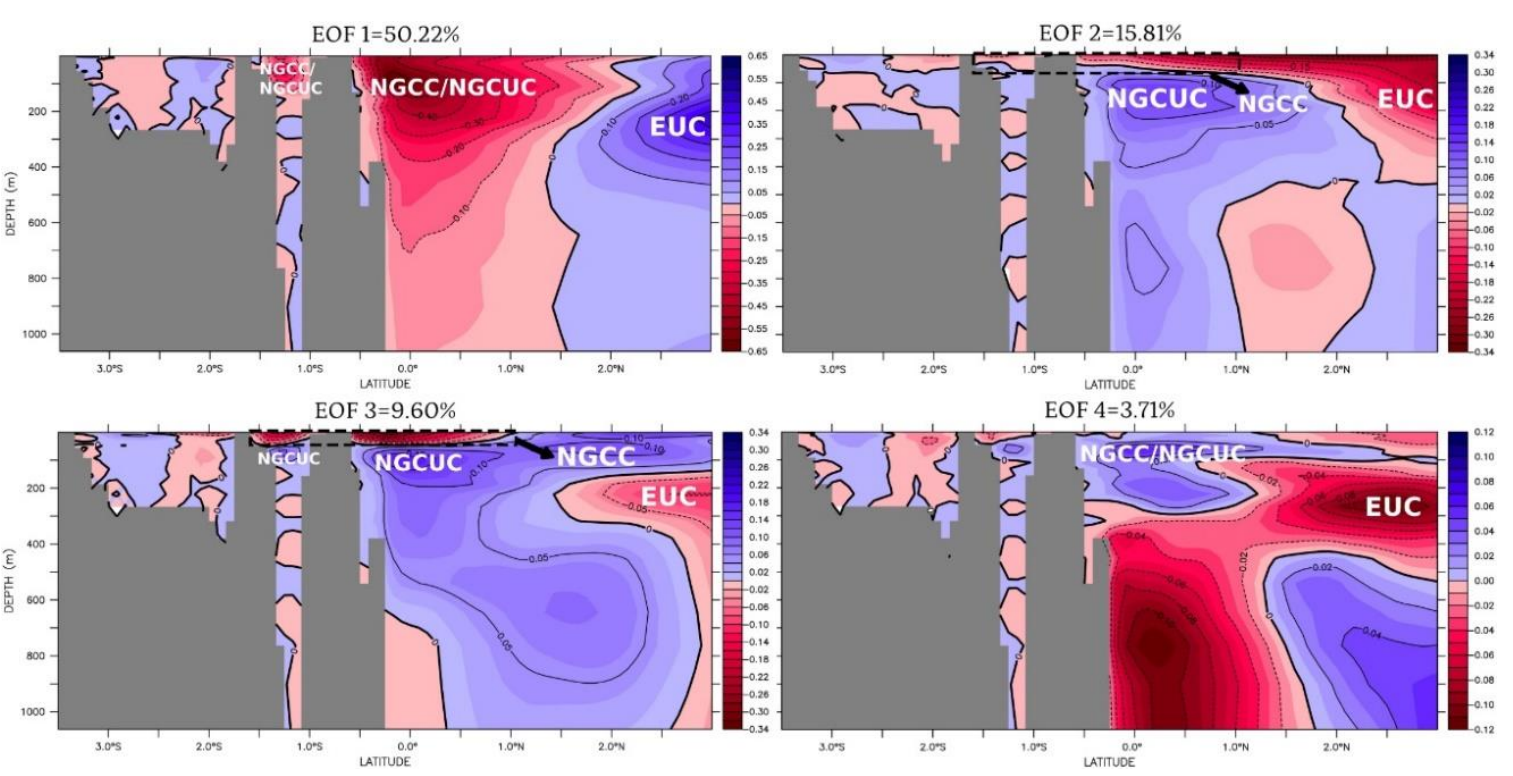

Gambar 10. Struktur spasial arus zonal di transek A-B tahun 2008-2015.
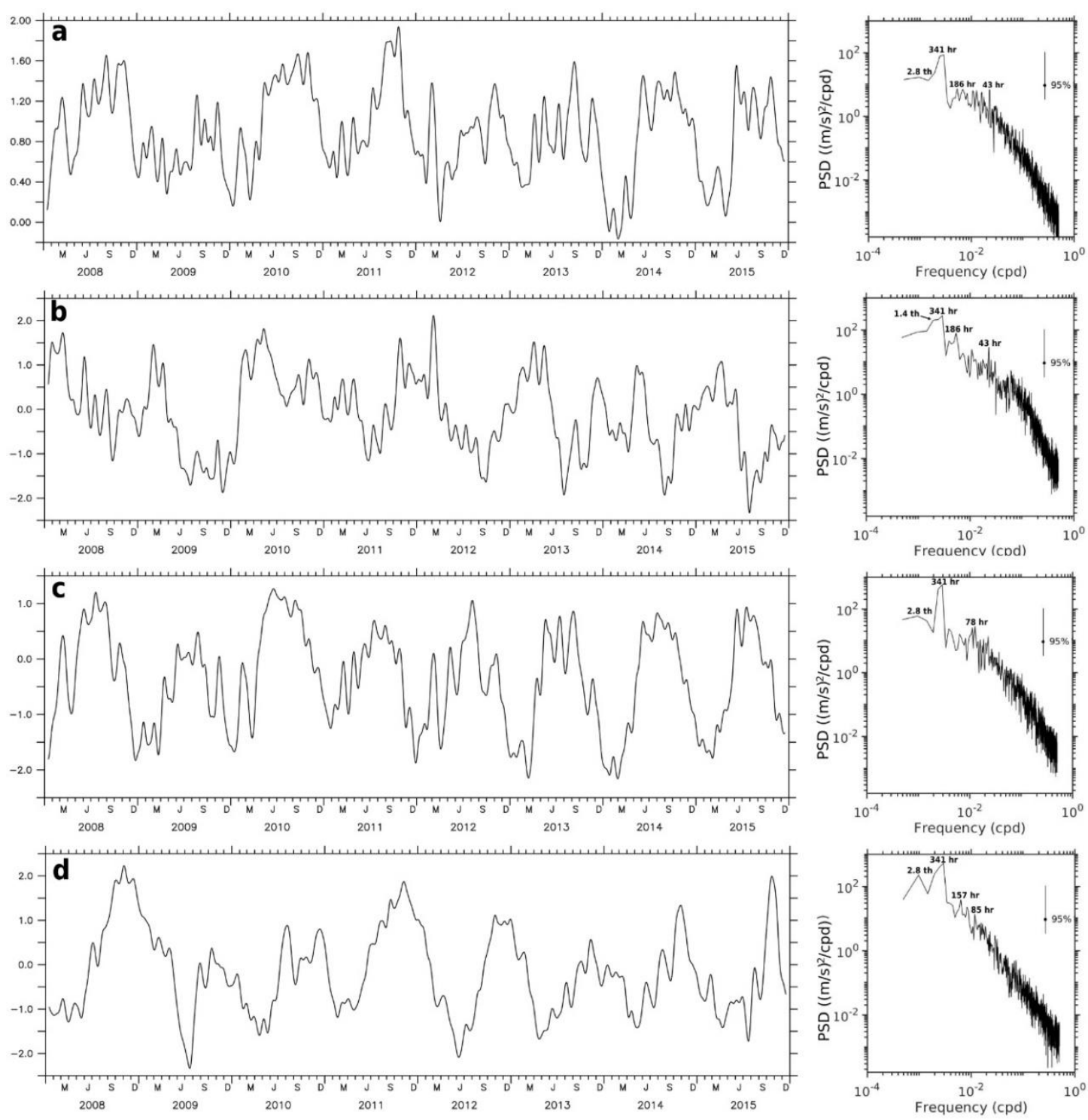

Gambar 11. Variasi temporal dan analisis PSD (a) PC 1, (b) PC 2, (c) PC 3 dan (d) PC 4 tahun 2008-2015. 
Wattimena et al [20] yang mendapatkan dominan sinyal tahunan dari arus NGCC/NGCUC Utara Papua.

\section{F. Biogeokimia}

Parameter biogeokimia (nitrat, fosfat, silikat dan produktivitas primer bersih - NPP) hasil keluaran model dari tahun 2008-2015 diplotkan pada dua sampling box yang berada di Pasifik (garis hitam) dan TC (garis merah) yang dapat dilihat pada Gambar 12.

Parameter nitrat di TC secara umum memiliki nilai yang lebih rendah dibandingkan dengan di Pasifik. Hal ini diduga disebabkan oleh pengaruh arus NGCC yang membawa zat hara [11]. Konsentrasi nitrat $\left(\mathrm{NO}_{3}\right)$ di TC dan Pasifik memiliki nilai mencapai $0,00103 \mathrm{mg} / \mathrm{L}$ dan $0,05930 \mathrm{mg} / \mathrm{L}$.
Hasil analisis PSD (Gambar 12a), data deret waktu nitrat di TC memiliki periodisitas energi signifikan yang terjadi pada skala-waktu antar tahunan $(2,8$ tahun), tahunan (341 hari), semi tahunan (157 hari) dan intra musiman (14 hari), yang terlihat sama kuat. Sedangkan di Pasifik, periodisitas energi signifikan dominan terjadi pada skala waktu antar tahunan (1,8 tahun) dan juga terlihat adanya skalawaktu semi-tahunan (186 hari). Periodisitas dari antar tahunan di TC dan Pasifik diduga disebabkan oleh adanya fenomena ENSO yang mempengaruhi dari konsentrasi nitrat.

Peristiwa El Nino di TC menimbulkan konsentrasi nitrat meningkat akibat adanya pengaruh coastal upwelling [21], sedangkan di Pasifik konsentrasi nitrat pada musim peralihan satu tahun 2010 dan 2015 menjadi rendah.
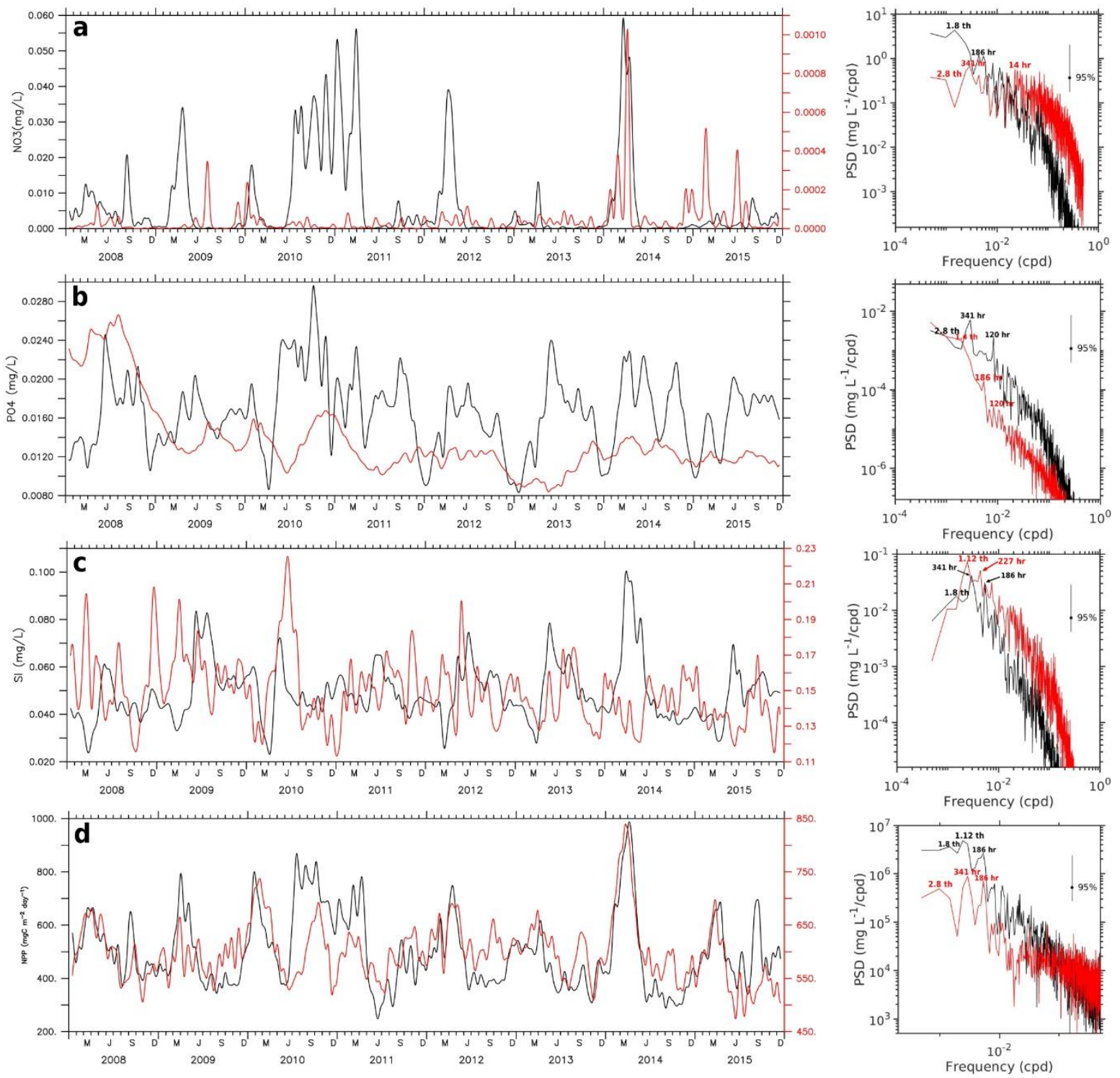

Gambar 12. Data deret waktu dari parameter (a) nitrat, (b) fosfat, (c) silikat dan (d) NPP, serta analisis PSD pada bagian kanan. Garis hitam menunjukkan nilai di Pasifik dan garis merah menujukan nilai di TC. 
Peristiwa La Nina 2010 membuat konsentrasi nitrat di Pasifik menjadi tinggi pada musim timur dan peralihan dua. Konsentrasi nitrat di Pasifik secara umum tinggi di musim peralihan satu (MAM) dan rendah pada musim lainnya. Rendahnya konsentrasi nitrat di Pasifik diduga akibat adanya pengaruh pusaran arus/eddy downwelling yang muncul pada musim timur dan peralihan dua, serta arus permukaan NGCC pada musim barat yang berubah arah menuju timur.

Konsentrasi fosfat $\left(\mathrm{PO}_{4}\right)$ di TC dan Pasifik masing-masing memiliki nilai 0,008402-0,02662 mg/L dan 0,008317-0,02965 mg/L. Berdasarkan hasil analisis PSD (Gambar 12b), data deret-waktu fosfat di TC memiliki periodisitas energi signifikan yang dominan pada skala-waktu antar tahunan (1,4 tahun) dan telihat adanya skala semi-tahunan (186 dan 120 hari). Sedangkan periodisitas energi signifikan di Pasifik dominan pada skala-waktu tahunan (341 hari) dan terlihat adanya skala-waktu antar tahunan (2,8 tahun) dan semi-tahunan (120 hari). Konsentrasi fosfat di Pasifik secara umum rendah pada musim barat dan tinggi saat bulan Mei dan Juni. Hal ini dapat disebabkan oleh arus NGCC yang saat musim barat bergerak menuju timur. Pengaruh fenomena ENSO terlihat mempengaruhi sebaran fosfat di TC. Nilai kandungan fosfat lebih tinggi pada periode La Nina karena terjadi peningkatan curah hujan yang menyebabkan peningkatan limpasan sungai yang membawa zat hara ke laut.
Konsentrasi silikat (Si) di TC memiliki nilai yang lebih tinggi dari pada di Pasifik. Hal ini dapat disebabkan pengaruh run-off sungai dan nilai salinitas yang ada di TC lebih rendah dibanding Pasifik, dimana silikat memiliki nilai yang berbanding terbalik dengan salinitas [22,23]. Konsentrasi silikat di TC dan Pasifik masing-masing memiliki nilai 0,1132-0,2255 mg/L dan 0,023090,1005 mg/L. Hasil analisis PSD menunjukkan bahwa data deret waktu silikat di TC dan Pasifik memiliki periodisitas energi siginifikan dominan yang terjadi pada skala waktu tahunan (1.12 tahun dan 341 hari) dan terlihat juga skala waktu antar tahunan (1,8 tahun), semi tahunan (186 dan 227 hari). Konsentrasi silikat di TC dan Pasifik secara umum rendah di musim peralihan satu dan tinggi di musim timur.

Rata-rata produktivitas primer bersih (NPP) di TC adalah 599,6 $( \pm 55,76) \mathrm{mgC} \mathrm{m}^{-2}$ day $^{-1}$, sedangkan di Pasifik sebesar 499,7 $( \pm 139,5) \mathrm{mgC} \mathrm{m}^{-2}$ day $^{-1}$. Hasil analisis PSD memperlihatkan data deret waktu NPP di TC dan Pasifik memiliki periodisitas energi siginifikan yang terjadi pada skala waktu antar tahunan (2,8 dan 1,8 tahun), tahunan (1.12 tahun dan 341 hari) dan semi tahunan (186 hari). Nilai NPP di perairan dipengaruhi salah satu nya oleh nutrien [24]. Pola dari NPP terlihat mengikuti dari parameter nutrien, dimana secara umum NPP di TC dan Pasifik memiliki nilai tertinggi pada musim peralihan satu dan relatif konstan di musim peralihan dua dan Timur, yang terlihat di parameter nitrat akibat adanya eddy downwelling.

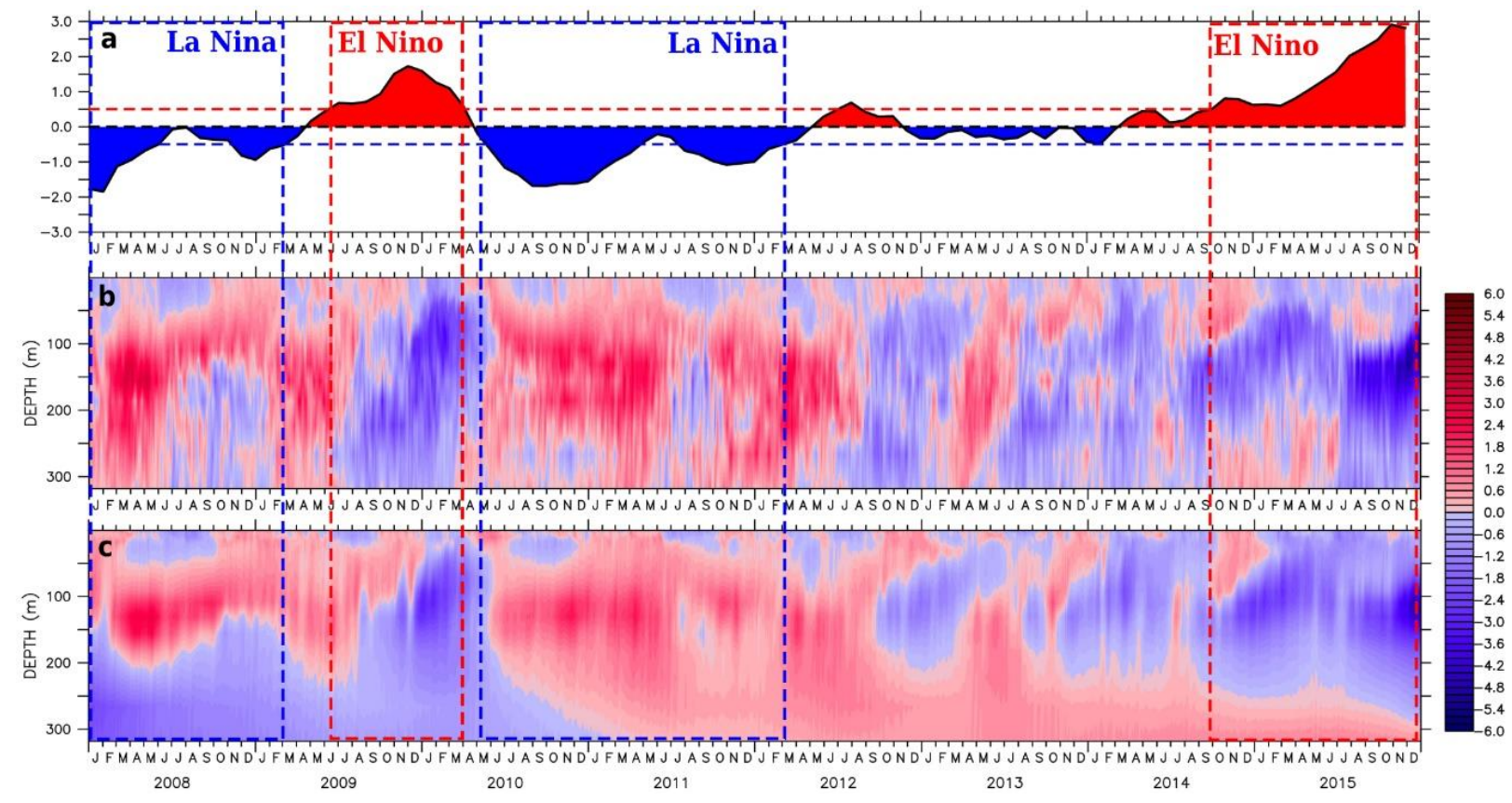

Gambar 13. (a) indeks nino 3,4, diagram waktu-kedalaman anomali suhu (a) Pasifik dan (b) TC. 


\section{F. Koherensi Parameter Suhu dan Arus dengan SST dan Angin Zonal wilayah Indo- Pasifik}

Diagram waktu-kedalaman (Gambar 13) menunjukkan anomali suhu di dalam sampling box TC dan Pasifik. Secara visual, pengaruh fenomena ENSO di TC dan Pasifik tidak terlihat di permukaan, tetapi terlihat berada di kedalaman 50 - $200 \mathrm{~m}$ (TC) dan 50 - 350 m (Pasifik). Fenomena ENSO diketahui memberi dampak terhadap anomali suhu di wilayah Pasifik ekuator bagian Barat, dimana suhu permukaan laut menjadi lebih dingin sat El Nino dan berkebalikan pada kondisi La Nina [25-27]. Hal ini terlihat pada Gambar 13 bahwa saat periode El Nino (2009-2010; 2015-2016) anomali suhu menjadi lebih dingin dan pada periode La Nina (2008-2009; 2011-2012) anomali suhu di kedua lokasi tersebut menjadi lebih hangat. Korelasi suhu di TC dan Pasifik di kedalaman $150 \mathrm{~m}$ dengan Index Nino 3.4 yang telah dilakukan filter, mendapatkan nilai koefisien korelasi kuat yaitu -0,89.

Analisis cross-PSD antara SST Indo-Pasifik dan suhu kedalaman 150 m di utara TC (Gambar 14) menghasilkan nilai koherensi yang tinggi mencapai nilai 0,9 di wilayah ekuator Pasifik yang merupakan daerah propagasi ENSO. Penelitian $\mathrm{Hu}$ et al [28] menyajikan pergeseran wilayah warmpool pada periode ENSO dari ekuator Pasifik Barat sampai ekuator Pasifik Timur. Beda fase memperlihatkan SST ekuator Pasifik mendahului suhu kedalaman $150 \mathrm{~m}$ di utara TC. Hal ini mengindikasikan bahwa variabilitas antar tahunan dari suhu kedalaman 150 m dipengaruhi oleh fenomena ENSO. Analisis crossPSD angin zonal Indo-Pasifik dan arus zonal (0-800 m) utara TC (Gambar 15) menghasilkan koherensi mencapai nilai 0,76 di wilayah bawah ekuator Pasifik. Hasil dari beda fase memperlihatkan bahwa angin zonal di bawah ekuator Pasifik tertinggal dari arus zonal di luar TC. Hal ini mengindikasikan adanya gaya pembangkit lain yang mempengaruhi variabilitas arus di kawasan TC.

\section{Kesimpulan}

Sirkulasi arus di kawasan TC dicirikan dengan eksistensi arus kuat dari NGCC/NGCUC di sisi utara TC atau sisi Pasifik dan Selat Biak sampai dengan $2^{\circ} \mathrm{N}$. Arus NGCC terlihat berada di kedalaman $0-50$ $m$ yang berbalik arah dua kali sesuai dengan arah pola angin muson, sedangkan arus persisten dan kuat dari NGCUC berada di kedalaman termoklin hingga $1000 \mathrm{~m}$ memiliki kecepatan arus tertinggi di kedalaman 100 mencapai $0,75 \mathrm{~m} / \mathrm{s}$, mengalir ke arah barat laut di semua musim dan membentuk pusaran arus/eddy downwelling di musim timur. Sirkulasi arus permukaan di TC cenderung selalu
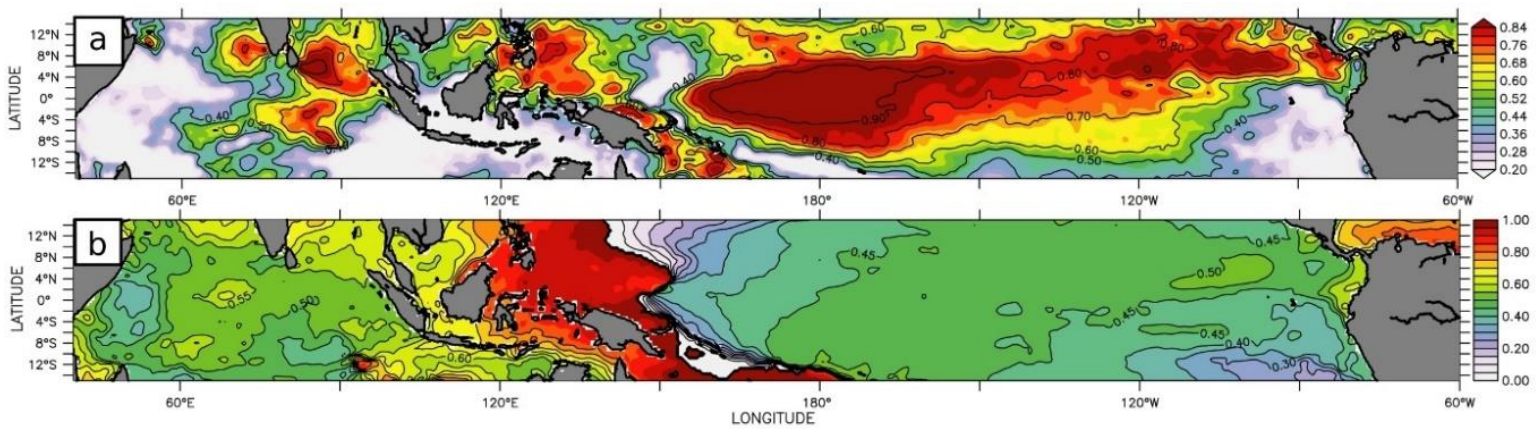

Gambar 14. (a)Koherensi dan (b) fase antara suhu kedalaman 150 m Pasifik dan SST Indo-Pasifik skala waktu antar tahunan (1023 hari).
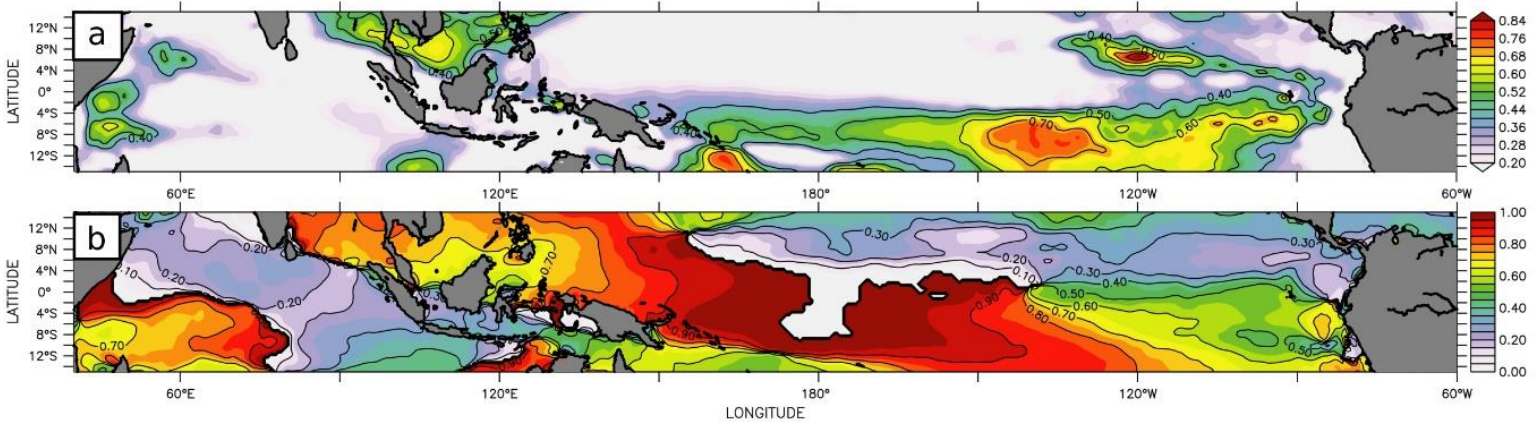

Gambar 15. (a)Koherensi dan (b) fase antara arus zonal (0-1000 m) Pasifik dan angin Indo-Pasifik skala waktu antar tahunan (1023 hari). 
mengalir keluar teluk dan adanya arus yang selalu bergerak masuk ke dalam teluk di kedalaman lebih dari $50 \mathrm{~m}$.

Rata-rata volume transpor NGCUC/NGCUC di Pasifik berkisar $-32,33( \pm 20,06)$ Sv dan di Selat Biak berkisar $-0,8756( \pm 0,5)$ Sv. Variabilitas dari volume transpor NGCC/NGCUC didominasi oleh skalawaktu tahunan. Arus yang keluar dan masuk teluk di pintu barat memiliki rata-rata volume transpor sebesar 0,4279 $( \pm 0,1341)$ Sv dengan terlihat variabilitas dalam skala-waktu dominan tahunan dan intra musiman.

Variabilitas konsentrasi biogeokimia di TC dan Pasifik dipengaruhi oleh beberapa skala-waktu dominan, seperti antar tahunan, tahunan, dan intra musiman. Pengaruh variabilitas antar tahunan yaitu ENSO terlihat juga mempengaruhi dari parameter suhu di TC dan Pasifik pada kedalaman 150 m, dimana hasil cross-PSD suhu kedalaman 150 $m$ di luar TC berkoherensi tinggi $(0,9)$ dengan SST ekuator Pasifik. Arus di luar TC juga memperoleh koherensi yang cukup tinggi dengan angin zonal di wilayah bawah ekuator Pasifik.

\section{Ucapan Terima Kasih}

Penulis mengucapkan terimakasih kepada pengelola program INDESO, Badan Penelitian dan Observasi Laut (BPOL) Perancak Bali dan CLS Toulouse Prancis.

\section{Daftar Pustaka}

[1] Allen, G. R. and Erdmann, M. V., Reef fishes of the Bird's Head Peninsula, West Papua, Indonesia, Check List, 5(3), 2009.

[2] Veron, J. E. N., Devantier, L. M., Turak, E., Green, A. L., Kininmonth, S., Stafford-Smith, M. and Peterson, N., Delineating the Coral Triangle, Galaxea, Journal of Coral Reef Studies, 11(2), 2009.

[3] Wyrtki, K., Physical Oceanography of the Southeast Asian waters., Scietific Resultas of Marine Investigations of the South China Sea and the Gulf of Thailand, 2,1961.

[4] Permana, D. S., Analisis Data Meteorologi Dari Pemantau Cuaca Otomatis Berbagai Elevasi dan Data Radiosonde Di Papua, Jurnal Meteorologi dan Geofisika, 12(2), 2011.

[5] Deckker, P. De, The Indo-Pacific Warm Pool: Critical to World Oceanography and World Climate, Geoscience Letters, 3(1), (2016).

[6] Ueki, I., Kashino, Y. and Kuroda, Y., Observation of Current Variations Off the New Guinea Coast Including the 1997-1998 El Niño Period and Their Relationship with Sverdrup Transport,
Journal of Geophysical Research: Oceans, 108(7), 2003.

[7] Zhang, L., Wu, J., Wang, F., Hu, S., Wang, Q., Jia, F., Wang, F. and $\mathrm{Hu}, \mathrm{D}$., Seasonal and Interannual Variability of the Currents off the New Guinea Coast From Mooring Measurements, Journal of Geophysical Research: Oceans, 125(12), 2020.

[8] Kashino, Y., Ueki, I., Kuroda, Y. and Purwandani, A., Ocean Variability North of New Guinea Derived from TRITON Buoy Data, Journal of Oceanography, 63(4), 2007.

[9] Kawabe, M., Kashino, Y. and Kuroda, Y., Variability and linkages of New Guinea Coastal Undercurrent and Lower Equatorial Intermediate Current, Journal of Physical Oceanography, 38(8), 2008.

[10] Surinati, D. and Corvianawatie, C., Dinamika Massa Air di Sekitar Pulau-Pulau Kecil Terluar (PPKT) Perairan Utara Papua, Oseanologi dan Limnologi di Indonesia, 4(3), 2019.

[11] Harsono, G. and Damanik, R., Lumbung laut Papua, Pandiva Buku, 2017.

[12] Mackey, D. J., O’Sullivan, J. E. Os. and Watson, R. J., Iron in the Western Pacific: A Riverine or Hydrothermal Source for Iron in the Equatorial Undercurrent?, Deep-Sea Research Part I: Oceanographic Research Papers, 49(5), 2002.

[13] Tranchant, B., Reffray, G., Greiner, E., Nugroho, D., Koch-Larrouy, A. and Gaspar, P., Evaluation of an Operational Ocean Model Configuration at $1 / 12^{\circ}$ Spatial Resolution for the Indonesian Seas (NEM02.3/IND012) \&ndash; Part 1: Ocean physics, Geoscientific Model Development, 9(3), 2016.

[14] Taylor, K. E., Summarizing Multiple Aspects of Model Performance in a Single Diagram, Journal of Geophysical Research Atmospheres, 106(D7), 2001.

[15] Emery, W. J. and Thomson, R. E., Data Analysis Methods in Physical Oceanography - 3rd Edition, 2014.

[16] Bendat, J. S. and Piersol, A. G., Random Data: Analysis and Measurement Procedures: Fourth Edition, 2012.

[17] Kuroda, Y., Variability of Currents Off the Northern Coast of New Guinea, Journal of Oceanography, 56(1), 2000.

[18] Wang, Q., Wang, F., Feng, J., Hu, S., Zhang, L., Jia, F. and $\mathrm{Hu}, \mathrm{D}$., The Equatorial Undercurrent and Its Origin in the Region Between Mindanao and New Guinea, Journal of Geophysical Research: Oceans, 124(4), 2019.

[19] Wattimena, M. C., Atmadipoera, A. S., Purba, M., Nurjaya, I. W. and Syamsudin, F., Volume Transport Variability in the Western Equatorial Pacific and its Relations to 
Halmahera Throughflow, Pertanika Journal of Science and Technology, 29(2), pp.11711197, 2021.

[20] Wattimena, M. C., Atmadipoera, A. S., Purba, M., Nurjaya, I. W. and Syamsudin, F., Indonesian Throughflow (ITF) variability in Halmahera Sea and its Coherency with New Guinea Coastal Current, IOP Conf. Ser.: Earth Environ. Sci., 2018.

[21] Waas, H. J. D., Siregar, V. P., Jaya, I. and Gaol, J. L., Coastal Upwelling Under The Influence of Westerly Wind Burst in the North Of Papua Continent, Western Pacific, International Journal of Remote Sensing and Earth Sciences (IJReSES), 9(2), 2014.

[22] Pello, F. S., Adiwilaga, E. M., Huliselan, N. V. and Damar, A., Pengaruh Musim Terhadap Beban Masukkan Nutrien Di Teluk Ambon Dalam (Effect Of Seasonal On Nutrient Load Input The Inner Ambon Bay), Jurnal Bumi Lestari, 14(1), pp.63-73, 2014.

[23] Pradisty, N. A., Mardatilah, Siwi, W. E. R. and Surana, I. N., Variabilitas parameter lingkungan (suhu, nutrien, Klorofil-a, TSS) di Perairan Teluk Tolo, Sulawesi Tengah saat musim timur, Prosiding Seminar Nasional
Hasil-Hasil Penelitian Perikanan dan Kelautan ke-VI, pp. 515-528, 2017.

[24] Yogaswara, D., Distribusi dan Siklus Nutrien Di Perairan Estuari Serta Pengendaliannya, Oseana, 45(1), pp. 28-39, 2020.

[25] Qu, T., Song, Y. T. and Maes, C., Sea surface Salinity and Barrier Layer Variability in the Equatorial Pacific as Seen from Aquarius and Argo, Journal of Geophysical Research: Oceans, $119(1), 2014$.

[26] Singh, A., Delcroix, T. and Cravatte, S., Contrasting the Flavors of El Niño-Southern Oscillation using Sea Surface Salinity Observations, Journal of Geophysical Research: Oceans, 116(6), 2011.

[27] Zhu, J., Huang, B., Zhang, R. H., Hu, Z. Z., Kumar, A., Balmaseda, M. A., Marx, L. and Kinter, J. L. , Salinity anomaly as a trigger for ENSO events, Scientific Reports, 42014.

[28] Hu, S., Hu, D., Guan, C., Xing, N., Li, J. and Feng, J., Variability of the Western Pacific Warm Pool Structure Associated with El Niño, Climate Dynamics, 49(7-8), pp. 2431-2449, 2017. 